\title{
CARBON MATERIALS IN THE TREATMENT OF SOFT AND HARD TISSUE INJURIES
}

\author{
M. Blazewicz \\ Department of Special Ceramics, University of Mining and Metallurgy, al. Mickiewicza 30, \\ 30-059 Cracow, Poland
}

\begin{abstract}
Carbon-based implant materials are of interest because they are well accepted by the biological environment. Carbon fibrous materials developed in the Department of Special Ceramics of the University of Mining and Metallurgy in Cracow were tested in in vivo studies to determine their influence on the living body. For comparative purposes, different carbon fibers were prepared and subjected to different surface modifications. Carbon materials prepared in the form of braids were implanted in subcutaneous tissue of rabbits and into skeletal muscle of rats. Carbon fabrics were examined as scaffolds in reconstruction of bone defects.

The present study examined the synthesis-structureproperty relationships of fibrous carbon samples with respect to the tissue response. It was shown that the tissue response depends on the form of the material form, the degree of order of the crystallites, the surface state and microstructural parameters. Carbon fibers with higher crystallinity and a better-organized graphite structure were assimilated by the body with more difficulty and small particles coming from these materials were found in the regional lymph nodes. Low- carbonized carbon fibers (small crystallite size) underwent partial fragmentation and reacted with the biological environment by being gradually resorbed in the implantation site. The presence of acidic groups on the surface of the carbon fibers enhanced phagocytosis of the carbon material by macrophages. Depending on the surface state of carbon fibers different rates of bone wound healing were observed.
\end{abstract}

Key Words: Carbon implants, carbon fibers, surface modification, tissue response, in vivo study.

Address for correspondence:

M. Blazewicz

Department of Special Ceramics,

University of Mining and Metallurgy,

al. Mickiewicza 30,

30-059 Cracow,

Poland

E-mail: blazeew@uci.agh.edu.pl

\section{Introduction}

Over the past twenty-five years various carbon materials have been investigated in many areas of medicine (Bohem, 1966; Arru et al., 1987; Jockish et al., 1992; Vallana et al., 1993; Blazewicz et al., 1994; Carranza-Bencano et $a l ., 2000)$. The large range of papers presented in scientific journals is related to the spectacular chemical and physical properties of carbon materials. Carbon occurs in different lattice forms, from amorphous through intermediate to crystalline, e.g., hexagonal or regular lattice diamond. The broad range of applications of carbon materials in medicine is also the outcome of many preparation methods. Carbon implant materials can be produced by pyrolysis of solid, liquid and gaseous carbon precursors. The pyrolysis method applied to carbon compounds allows the production of carbon of different structure and microstructure in the form of thin films or thick layers, solid pyrolytic carbon, powders and in the form of fibers (Pampuch et al., 1988). The different forms of carbon that have received attention are artificial graphites, glasslike carbon, carbon fibers, pyrolytic carbon and vaporgrown carbon coatings. Among pure forms of carbon, the pyrolytic carbons and carbon coatings on various substrates have found clinical applications in the cardiovascular, orthopedic and dental areas as well as in long-term transcutaneous applications (Bokros et al., 1972; Buttazzoni, 1987; Feng and Andrade, 1994; Louis and Dabadie, 1996; De Santis et al., 2000).

Carbon fibers represent transition graphite structures obtained mainly by a carbonization process of organic fibers. The process makes it possible to retain the fibrous form of the precursor. However, the carbon atom arrangement is similar to that in graphite. The major difference between the structure of graphite and carbon fibers is that, at the atom level, the degree of structural ordering in the carbon fibers is present only in the basal planes. The physical and chemical properties of carbon fibers are also determined by their microstructure. This is particularly important in the case of carbon fibers used in medicine. The size of coherent crystallites in carbon fiber lattice, corresponding to the crystallite thickness $\left(\mathrm{L}_{\mathrm{a}}\right)$ and crystallite height $\left(\mathrm{L}_{\mathrm{c}}\right)$ is of decisive importance for, e.g., fiber resistance to oxidation and, in a biological environment, may influence the interaction between the fiber and the environment (Blazewicz et al., 1991).

One of the earliest medical uses of carbon fibers was replacement or repair of ligaments and tendons (Forster 
et al., 1978; Miller, 1984; Jenkins, 1985). Most of the studies on carbon fibrous implants confirm that carbon fibers do not inhibit tissue growth, and thus can act as a scaffold for tissue proliferation (Forster et al., 1978; Becker et al., 1996). Controversy surrounds the mechanism of the disintegration and removal of the implanted carbon fibers. A histological study showed that the carbon fibers gradually broke down and migrated into the nearest lymph nodes with no apparent detrimental effect (Becker et al., 1996). In all instances the carbon fibers acted as a scaffold that allowed the regeneration of tendon and ligament. In contrast to these investigations, Morris et al. (1990) showed that fragmentation of fibers did not occur and implant debris was not found in the regional nodes. Moreover, carbon fibers induced significantly more tissue ingrowth than polypropylene mesh at 6 to 12 months postoperatively. A probable elimination mechanism by erosion of carbon particles and their retention in the fibrous capsule surrounding the implant was suggested by More et al. (1988). Although the results of most investigations of carbon fibers in vivo were evaluated as good, several authors were skeptical as to the superiority of carbon fibrous implants over other prosthetic materials (Strover and Firer, 1985; Alexander et al., 1987).

In a review by Christel et al. (1991) carbon fibers were considered to be a good candidate biomaterial for total hip replacement and internal fixation in the form of composites. In spite of controversial results with carbon fibers used for replacement and reconstruction of ligaments and tendons, several other clinical studies were undertaken. Carbon fibers were studied as construction material in keratoprosthesis (Kain, 1990), and their use in the repair of joint surfaces and as scaffolds (Robinson et al., 1993; Brittberg et al., 1994) as well as in bone defect treatment (Abusafieh et al., 1997; Lewandowska et al., 1999) was considered.

The different results obtained in evaluating carbon fibers as a biomaterial can probably be explained by the use of different types of carbon fibers of different physical, structural and chemical properties, resulting from many technological parameters. Most of the papers concerning examinations of carbon fibers for medical purposes describe neither the type of carbon fibers used nor their fundamental properties determining their behavior in a biological environment.

Several years of experience of the research group at the University of Mining and Metallurgy in Cracow (Poland) have resulted in the development of various forms of carbon biomaterials based on specific carbon fibers. Depending on the method of preparation and on the carbon precursors various carbon materials in different forms (braids, fabrics, cloths, $\mathrm{C} / \mathrm{C}$ composites) with different biological behavior have been manufactured (Pampuch et al., 1988; Blazewicz et al., 1994, 1996, 1997; Chlopek, 2000).

The aim of the present paper was to demonstrate that carbon fibers can be differently tolerated by a living organism, depending on their manufacturing and final modification. Carbon fibers in the form of braids with specific structural, microstructural and chemical characteristics were examined in soft tissue, while carbon fibers in the form of unwoven fabric were used as scaffolds in reconstruction of experimentally prepared bone defects.

\section{Materials and Methods}

Carbon fibrous implants prepared in the laboratory were used in this study. Polyacrylonitrile precursor (PAN) with co-monomer (6 $\mathrm{wt} \%$ methyl acrylate and $1 \mathrm{wt} \%$ itaconic acid) was used to prepare carbon fibers.

The yarns of PAN fibers containing 300 filaments of 13-14 $\mu \mathrm{m}$ diameter were transformed into braids and unwoven fabrics. These two types of carbon precursors were subjected to thermal processing, first in air atmosphere (stabilization step) and then in pure argon (carbonization) (Blazewicz et al., 1989). The physical and chemical properties of carbon implants obtained by carbonization were modified by means of different techniques including high temperature treatment, oxidative surface treatment and vapor-grown carbon coating.

\section{Temperature treatment}

Two kinds of carbon braids were heat-treated at different final temperatures in an argon atmosphere, namely at $1200^{\circ} \mathrm{C}$ and at $2700^{\circ} \mathrm{C}$. The structural parameters of these carbon samples are presented in Table 1. The structural parameters of carbon fibers obtained at $2700^{\circ} \mathrm{C}$ and their other technical data (Young 's modulus, tensile strength, strain to failure, elemental composition) are typical for technical carbon fibers used in many areas in leisure products and industrial developments, particularly in aerospace materials (Donnet and Bansal, 1986).

\section{Oxidative surface treatment}

Carbon braids obtained at $1200^{\circ} \mathrm{C}$ were subjected to further surface modification by means of oxidative treatment. The samples of carbon braids were oxidized in boiling nitric acid for 30 minutes. The amount of acidic and basic groups on the fiber surface was determined by neutralization with $0.01 \mathrm{~N} \mathrm{NaOH}$ and $0.01 \mathrm{~N} \mathrm{HCl}$ solutions, respectively. The method of identification of chemical surface groups on carbon materials has been described by Bohem (1966) and Bohem (1994). The chemical characteristics of the samples before and after modification are summarized in Table 2.

\section{Vapor-grown coating}

This technique was applied to carbon unwoven fabrics. The samples of carbon fabrics were coated with a thin pyrolytic carbon layer $(0.2 \mathrm{~mm})$ formed by thermal decomposition of methane at $1050^{\circ} \mathrm{C}$ for 10 minutes. The physical and chemical characteristics of carbon fabrics are shown in Table 3.

\section{In vivo experiments - soft tissue}

Carbon fibers in the form of braids of different crystallite size were implanted in subcutaneous tissues of rabbits, whereas the fibers with different surface states were implanted into skeletal muscle of rats.

Young New Zealand rabbits of both sexes were used in the first experiment. Surgery was performed in the aseptic operation room of the Central Animal Laboratory of the Silesian Medical Academy in Katowice (Poland). Animals were maintained under guidelines set forth in the Principles of Laboratory Care and the Guide for the Care and Use of Laboratory Animals. In all experiments 
Table 1. Parameters of carbon braids obtained at various temperatures.

\begin{tabular}{|l|l|l|l|l|l|}
\hline $\begin{array}{l}\text { processing } \\
\text { temperature }\end{array}$ & $\begin{array}{l}\text { strain to } \\
\text { failure }\end{array}$ & $\begin{array}{l}\text { fiber diameter } \\
( \pm \text { standard error) }\end{array}$ & \multicolumn{3}{|c}{$\begin{array}{c}\text { structural parameters } \\
( \pm \text { standard error) }\end{array}$} \\
\hline$\left({ }^{\circ} \mathrm{C}\right)$ & $(\%)$ & $(\mu \mathrm{m})$ & $\mathrm{L}_{\mathrm{c}}, \mathrm{A}$ & $\mathrm{L}_{\mathrm{a},} \mathrm{A}$ & $\mathrm{d}_{002,} \mathrm{~A}$ \\
\hline 1200 & 3.2 & $8.3 \pm 0.4$ & $11.4 \pm 0.8$ & $-*$ & 3.55 \\
\hline 2700 & 1.8 & $8.0 \pm 0.2$ & $50.2 \pm 2.8$ & $127 \pm 9$ & 3.37 \\
\hline
\end{tabular}

diffraction peaks corresponding to the three-dimensional ordering.

Table 2. Chemical properties of carbon braids.

\begin{tabular}{|l|l|l|l|}
\hline type of sample & \multicolumn{2}{|l|}{ concentration of surface groups } & surface-specific area \\
\hline & $\begin{array}{l}\text { acidic } \\
\mathrm{mol}\left[\mathrm{H}^{+}\right] / \mathrm{g} \mathrm{CB}\end{array}$ & $\left.\begin{array}{l}\text { basic } \\
\mathrm{mol}[\mathrm{OH}]\end{array}\right] \mathrm{g} \mathrm{CB}$ & $\begin{array}{l}\left(\mathrm{m}^{2} / \mathrm{g}\right) \\
( \pm \text { standard error })\end{array}$ \\
\hline non-modified $\left(1200^{\circ} \mathrm{C}\right)$ & $1.25 \times 10^{-4}$ & $1.9 \times 10^{-4}$ & $0.48 \pm 0.03$ \\
\hline $\begin{array}{l}\text { oxidized with boiling } \\
\text { nitric acid }\end{array}$ & $1.04 \times 10^{-3}$ & $7.51 \times 10^{-4}$ & $0.56 \pm 0.03$ \\
\hline
\end{tabular}

CB: carbon braid.

Table 3. Physical and chemical parameters of unwoven carbon fabrics.

\begin{tabular}{|c|c|c|c|c|c|c|c|c|c|}
\hline \multirow{2}{*}{$\begin{array}{ll}\begin{array}{l}\text { type } \\
\text { sample }\end{array} \\
\end{array}$} & \multicolumn{2}{|c|}{ concentration of surface groups } & \multicolumn{5}{|c|}{ elementary analysis (\% wt) } & \multirow{2}{*}{\begin{tabular}{|l} 
weight \\
$\left(\mathrm{g}^{\prime} \mathrm{m}^{\mathrm{s}}\right)$ \\
\end{tabular}} & \multirow{2}{*}{ 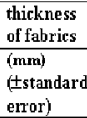 } \\
\hline & $\begin{array}{l}\text { Axidie } \\
\text { mol }\left[\mathrm{H}^{+}\right] \mathrm{g} \mathrm{CB}\end{array}$ & $\begin{array}{l}\text { besic } \\
\text { mol[ } \mathrm{OH}] / \mathrm{g} \mathrm{CB}\end{array}$ & $\mathrm{c}$ & N & $\mathbf{H}$ & 0 & osh & & \\
\hline $\begin{array}{l}\text { Group I } \\
\text { (oxidized } \\
\text { sith boiling } \\
\text { nitric acid) }\end{array}$ & $3.4 \times 10^{-3}$ & $9.8 \times 10^{-4}$ & 81.0 & 6.0 & 0.8 & 9.0 & 3.2 & $237 \pm 21$ & 5 \\
\hline $\begin{array}{l}\text { Group II } \\
\text { (coated } \\
\text { with } \\
\text { pyrolytic } \\
\text { layer) }\end{array}$ & $3.3 \times 10^{5}$ & $6.2 \times 10^{-4}$ & 86.4 & 49 & 0.5 & 6.8 & 1.5 & $251+12$ & 5 \\
\hline
\end{tabular}

the animals were premedicated with Atropin and Relanium.

There were two experimental groups of rabbits. Before implantation, the carbon braids (approximately 10 $\mathrm{mm}$ in length and $0.6 \mathrm{~mm}$ in diameter) were washed in ethyl alcohol and steam-autoclaved at $250^{\circ} \mathrm{C}$ and $100 \mathrm{kPa}$ for $15 \mathrm{~min}$. The subcutaneous tissue was approached by cutting the skin on the side of the back of the animal. The implant was introduced through a pocket. The wounds were closed in layers with Dexon sutures (POLFA, Poznan, Poland; manufactured under license from American Cyanamid Co.). The experimental materials were retrieved from the rabbits after 4, 6, 8, 10 and 12 weeks, respectively. Within a given group there were thus five subgroups corresponding to the different periods that the implant was present in the animal. Each subgroup consisted of three animals. The tissue samples removed from the implant site together with adjoining tissue were subjected to a routine histological analysis. After fixation in 4\% formalin the samples were routinely embedded in Paraplast and cut into sections of $7 \mathrm{~mm}$ thick. Tissue sections were stained with hematoxylin and eosin (H\&E). A morphological description of the soft tissue surrounding and growing into the carbon implants was made.

Moreover, biodegradation of the carbon implants was analyzed by determining geometrical and physical changes in the fibers. This included the measurements of the average fiber width, the mean dimension of the carbon particles and their mean gray level. The carbon fibers were clearly visible in H\&E stained samples. Under the optical microscope and with the help of a computerized analysis system the pictures were saved as 24bits.tga files. The pictures were then analyzed by Visilog 4 and MicroEyse software, with an accuracy of 5\% according to the manufacturer (Noesis Immeuble Nungesser, Velezy, France). Fiber width was measured as the distance between the fiber contours, perpendicularly to the fiber axis. This parameter was only measured for the longer fragments of the fibers. The mean gray level corresponded to the optical density of the carbon implant. For total black the gray level equals 0 , whereas for a transparent substance this parameter is 256 . To calibrate the measurements, fragments of carbon fibers before implantation were used.

The internal organs of the rabbits (brain, lungs, kidneys, liver, spleen, adrenal glands and lymph nodes) after the longest implantation period (12 weeks) were examined by routine histology.

Another type of carbon braids, subjected to chemical treatment, was implanted into skeletal muscle of male Wistar rats. The experiments were carried out with the two types of carbon braids shown in Table 2 . The samples for histological analysis were prepared similarly to those described earlier. The experiments lasted from 2 to 210 days. The analyses considered in particular the number of macrophages and fibroblasts at the implant site. The sections were observed by light microscopy and parameters were determined by computerized image analysis.

\section{In vivo experiments - hard tissue}

Two types of carbon fibres in the form of unwoven fabrics were examined in hard tissue. The chemical and physical parameters of the samples used in these experiments are summarized in Table 3 . The samples were implanted into experimentally prepared bone defects of rabbits.

After premedication, the surgery was performed in the following way: the lateral surface of the mandible was exposed through a bilateral cut at its base. Next, bone defects of $6 \mathrm{~mm}$ in diameter and $3 \mathrm{~mm}$ depth were made by drilling in both lateral surfaces. The prepared defects were filled with two types of carbon scaffolds with different surface state (Table 3). The defects of the control group were left to be filled only with a blood clot. The wounds were closed with Dexon sutures. The samples were retrieved from the implant site after an implantation time varying from 7 days to 12 weeks, and fixed in $10 \%$ neutralized formalin solution. Fragments of mandibular bone tissue were decalcified in EDTA and embedded in Paraplast. The blocks were then cut on a microtome to produce $6 \mathrm{~mm}$ thick sections. After removal of the Paraplast the sections were stained routinely with $\mathrm{H} \& \mathrm{E}$ and subjected to histological evaluation.

\section{Results and Discussion}

\section{Soft tissue - effect of crystallite size on tissue response:}

Analysis of carbon implants in the form of braids obtained at $1200^{\circ} \mathrm{C}$ implanted into subcutaneous tissue of rabbits. Already 4 weeks after implantation the surface of fibers became rough and showed the presence of carbon grains. The sites of the implants were distinctly 

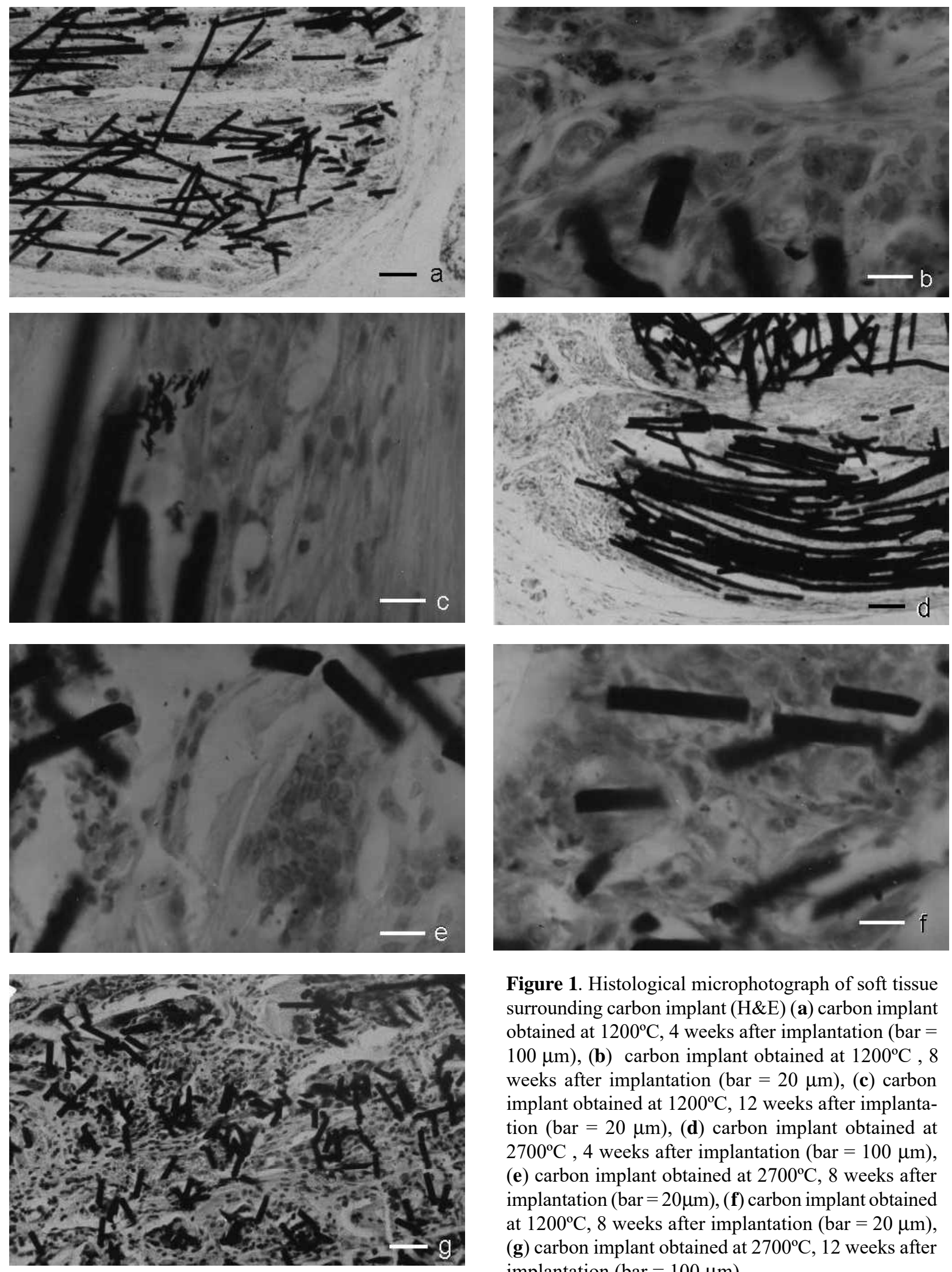

Figure 1. Histological microphotograph of soft tissue surrounding carbon implant (H\&E) (a) carbon implant obtained at $1200^{\circ} \mathrm{C}, 4$ weeks after implantation $($ bar $=$ $100 \mu \mathrm{m}),(\mathbf{b})$ carbon implant obtained at $1200^{\circ} \mathrm{C}, 8$ weeks after implantation (bar $=20 \mu \mathrm{m}),(\mathbf{c})$ carbon implant obtained at $1200^{\circ} \mathrm{C}, 12$ weeks after implantation (bar $=20 \mu \mathrm{m})$, (d) carbon implant obtained at $2700^{\circ} \mathrm{C}, 4$ weeks after implantation $($ bar $=100 \mu \mathrm{m})$, (e) carbon implant obtained at $2700^{\circ} \mathrm{C}, 8$ weeks after implantation (bar $=20 \mu \mathrm{m}),(\mathbf{f})$ carbon implant obtained at $1200^{\circ} \mathrm{C}, 8$ weeks after implantation (bar $\left.=20 \mu \mathrm{m}\right)$, (g) carbon implant obtained at $2700^{\circ} \mathrm{C}, 12$ weeks after implantation (bar $=100 \mu \mathrm{m})$. 


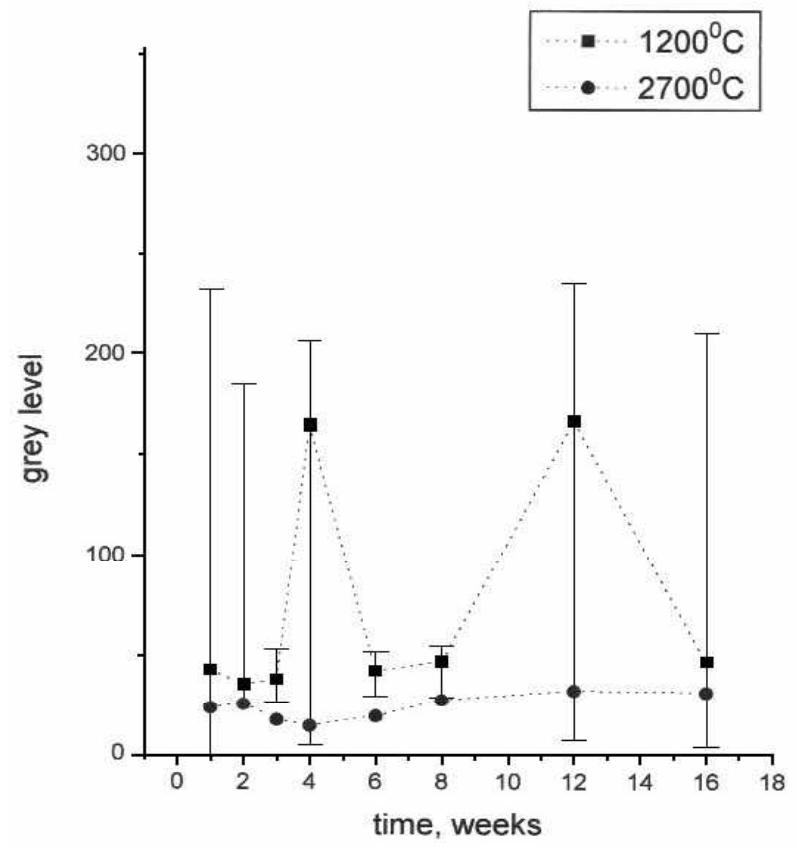

Figure 2. Changes of mean gray level of carbon fibers obtained at $1200^{\circ} \mathrm{C}$ and $2700^{\circ} \mathrm{C}$ as a function of implantation time (median, and 25 and 75 percentiles are shown).

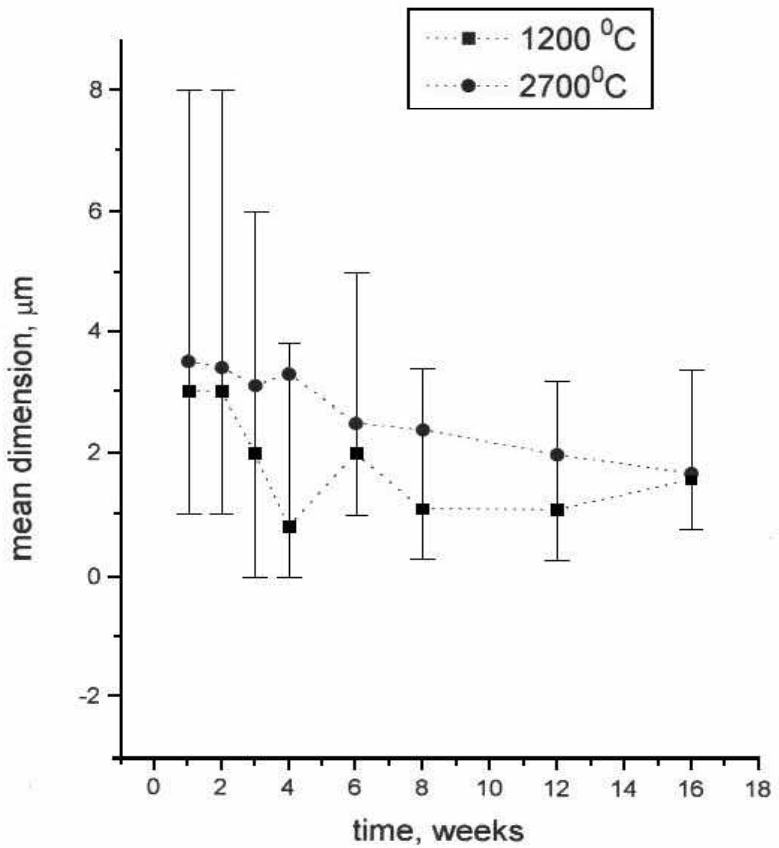

Figure 3. Variations of mean dimension of carbon particles as a function of implantation time separated from the surrounding tissue by a sheath of fibrous connective tissue containing fibroblasts and a significant amount of collagen fibers (Fig. 1a). The average fiber width was reduced by about $0.6 \mathrm{~mm}$. The fibers were clearly fragmented into smaller pieces, the length of which decreased with the time of implantation. Smaller fragments of fibers observed under higher magnification were spherical, without sharp edges. Phagocytes containing carbon particles were observed at the implant site (Fig.1b). In the 12-week series the presence of carbon debris accompanying larger fragments of fibers was observed (Fig. 1c). As the experiment continued, the connective tissue sheath became much thinner or disappeared. After longer implantation time granulation tissue and young connective tissue with rich vascularization were prevailing. Reparative tissue developed as a normal process of wound healing.

Analysis of carbon implants in the form of braids obtained at $2700^{\circ} \mathrm{C}$ implanted into subcutaneous tissue of rabbits. The surface of the carbon fibers in all implants present from 4 to 12 weeks was smooth. The fibers in the implant removed after 4 weeks were still closely packed in bundles (Fig. 1d). The implants removed after longer periods contained carbon fibers that were partially fragmented. The fragmentation took place mainly perpendicularly to the fiber axis. The average width of the fibers was unchanged during the whole experiment. Microscopic studies showed a non-uniform tissue response, even in the samples from the same time of implantation. Phagocytes containing carbon material were not observed at the implants. In the microscopic images of implant sites after 8 weeks of implantation, foreign body giant cells not containing carbon material were detected (Fig. 1e). During the whole experiment the pres- ence of eosinophils was observed which indicates an allergic inflammatory reaction (Fig.1e,f,). The wound healing process advanced in a non-typical way similar to granuloma. In some cases necrotic changes was observed. Material from 12 week implant sites contained mainly short angular fiber fragments (Fig.1g).

The above analysis shows that carbon braids manufactured at $1200^{\circ} \mathrm{C}$ seem to be more biocompatible with the living body. The examined internal organs (brain, lungs, kidneys, liver, spleen, adrenal glands, lymph nodes) did not show any changes related to the implant nor did they show the presence of carbon particles.

Low-temperature fibers are easier assimilated by the body as compared to highly- crystalline carbon fibers obtained at a higher final temperature (higher $\mathrm{L}_{c}, \mathrm{~L}_{\mathrm{a}}$ ). The results of the histopathological examination of distant organs of rabbits after implantation with highly-crystalline carbon implants showed the presence of carbon debris in nearby lymph nodes only. It is probable that carbon fibers with a well-ordered graphite structure are more resistant to the cellular reaction of the host (oxidation process) and this material undergoes only partial, transverse fragmentation resulting from its high brittleness (cf. strain to failure, Table 1), followed by slow removal of carbon particles from the implant site by macrophages to the regional lymph nodes. Such a mechanism has also been postulated by other authors (Jenkins, 1985; Cieœlik et al., 1999). As mentioned above, this type of fibers has physical and mechanical parameters comparable to fibers used in technical applications.

In the case of low-carbonized fibers the process of degradation is more complex. Optical analysis showed significant variations in mean gray level with time for these two types of fibrous materials. As shown in Figure 2, the 


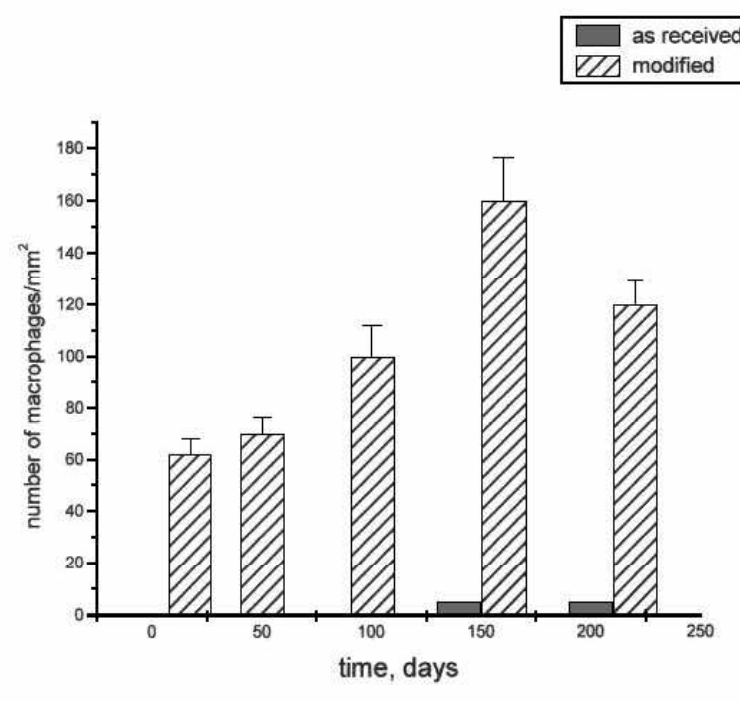

Figure 4. Variations of macrophages number in tissue surrounding carbon implants with the implantation time.

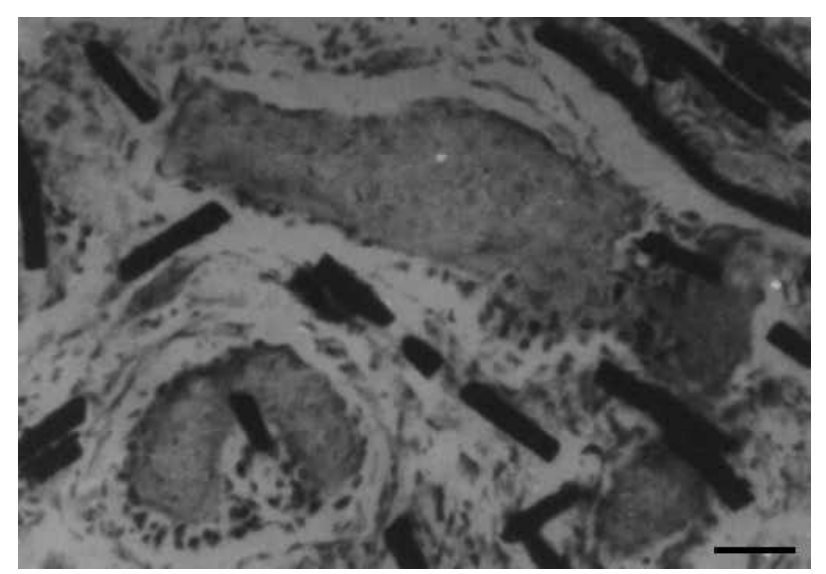

Figure 6. Bone trabeculae with numerous osteoblasts (H\&E); carbon implant II, 2 weeks after implantation (bar $=20 \mu \mathrm{m})$.

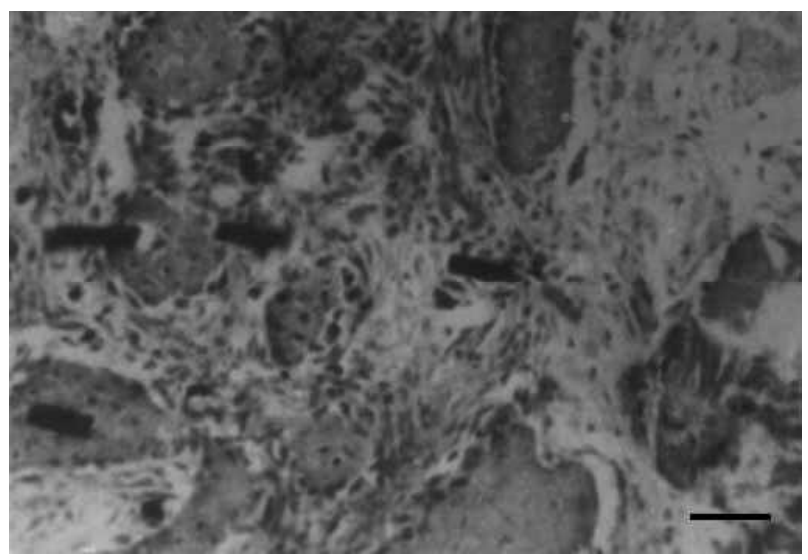

Figure 8. Osteoid trabeculae with minor osteoblasts (H\&E) carbon implant I, 2 weeks after implantation (bar $=20 \mu \mathrm{m})$.

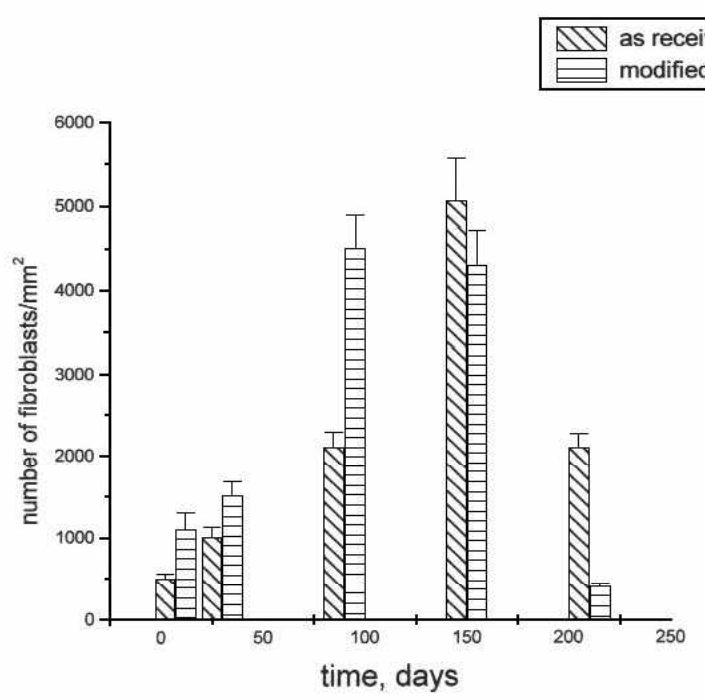

Figure 5. Variations of fibroblasts number in the implant site with the implantation time

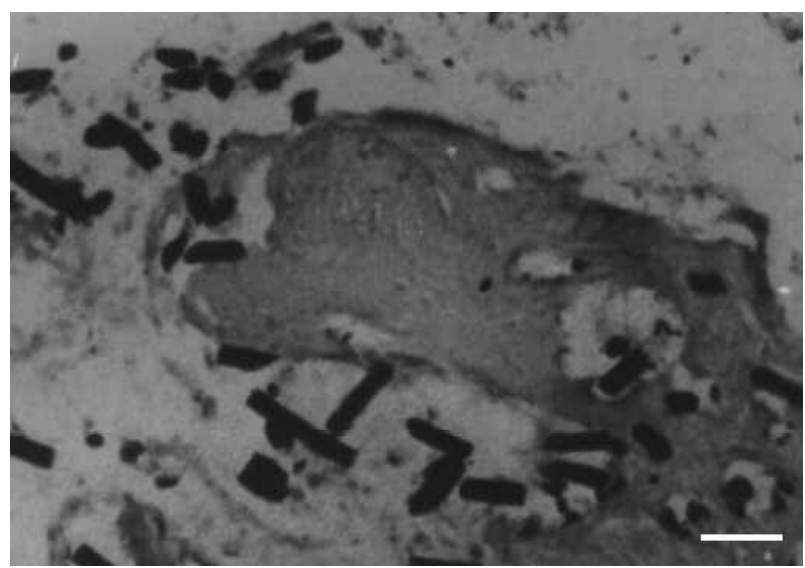

Figure 7. Spongy bone fully mineralized (H\&E), carbon implant II, 12 weeks after implantation (bar $=20$ $\mu \mathrm{m})$.

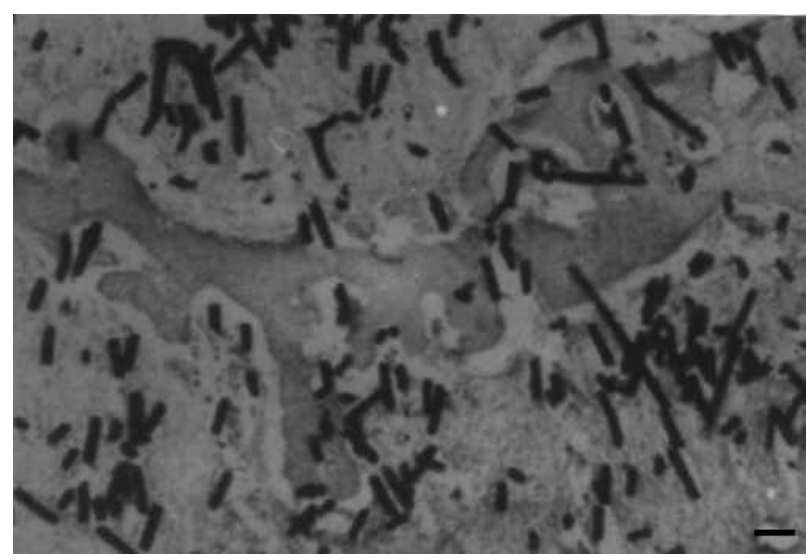

Figure 9. Mature bone partially mineralised (H\&E). Carbon implant I. 12 week after implantation (bar $=$ $50 \mu \mathrm{m})$. 
mean gray level of carbon implant obtained at $1200^{\circ} \mathrm{C}$ changes with the implantation time from 42.5 to 166.7 , while for carbon particles originating from fibers obtained at $2700^{\circ} \mathrm{C}$ this parameter was almost unchanged. Thus, the process of biodegradation of carbon samples with small crystallites can be considered as physical and chemical changes of fiber particles within the body. Physical changes result in transversal and longitudinal fragmentation and a decrease of the average dimension of carbon fiber particles as shown in Figure 3. On the other hand, chemical changes are responsible for the variation of optical density of the fibers and for the gradual decrease in width of the carbon fibers, particularly in the first weeks after implantation. The chemical changes are probably related to the oxidation process of low-carbonized carbon particles in body fluids (high chemical affinity to oxygen). As shown in Figure 2 structural changes (changes in optical density) are more pronounced in the case of low-carbonized carbon fibers.

\section{Soft tissue - effect of the surface state}

The nature of the interaction between the biological environment and the carbon implants is clearly influenced by the character of the implant surface. The next example demonstrates the effect of different surface state of carbon fibers on tissue response.

The results of analysis are shown in Figures 4 and 5. The diagrams show a variation in the number of macrophages containing carbon particles and the number of fibroblasts in the implant site plotted against implantation time. The data clearly indicate the effect of the surface state on macrophage and fibroblast activity. Modification of the surface of the carbon fibers by enrichment with chemical groups (see Table 2), mainly acidic in character, leads to a faster and intensified tissue response, which simultaneously can influence regeneration and repair time of the injured muscle (Zamorska et al., 1998). The effect of functional chemical groups of carbon materials on in vitro phagocytosis was also confirmed by Czajkowska et al. (1997).

\section{Hard tissue - effect of the surface state}

The light micrographs of the carbon implant sites in bone defects are shown in Figures 6 to 9. It can be concluded that depending on the type of carbon implant surface, different rates of bone wound healing could be observed resulting from different time sequences of tissue reaction, and production and organization of bone tissue. The bone regeneration process was more active in the group characterized by predominantly basic functional groups (group II) (Figs. 6 and 7). Faster bone maturation manifested by the presence of thick mature bone trabeculae occurred in this group. Slower regeneration was observed in group I (Figs. 8 and 9), while in the control group regeneration was clearly delayed. It seems that the presence of acidic groups on the carbon surface inhibits the bone repair process, compared to basic groups.

\section{Conclusions}

The experiments revealed that carbon implants in fibrous form undergo physical and biological transformations in a biological environment. The rate of these processes de- pends on the structural and microstructural parameters of the carbon implants. The physical process consists mainly of gradual fragmentation of carbon fibers. This process was observed in the case of carbon fibers obtained at high carbonization temperature. This type of fibers, with properties similar to technical fibers, behave as an inert material in a biological environment and fragmentation occurs probably due to direct dynamical loading of the surrounding tissue. Low-carbonized carbon fibers behave differently from the technical fibers: they undergo partial fragmentation and react with the biological environment by being gradually resorbed at the implantation site. The resorption of carbon implants by host tissues leads to thinning and structural transformation of the carbon structure probably due to partial oxidation. These fibers are more easily assimilated by the body.

The results indicated a distinct influence of the surface state of carbon fibers on macrophage activity and on bone tissue healing. Different rates of bone wound healing were seen in histological studies. The presence of acidic groups on the surface of implant enhanced phagocytosis of the material by macrophages in soft tissue, while the basic groups on the carbon surface were advantageous for regenerative processes of bone tissue.

This study showed that biological behavior of carbon fibrous materials may depend on the type of single fiber, its structure, chemical surface state and elemental composition. Hence, the usefulness of this material for medical use needs further study and laboratory experiments on technology of carbon materials designed specially for medical purposes should be carried out.

\section{Acknowledgements}

The author thanks Dr T. Zamorska from the Department of Pathology, Medical Academy of Cracow, and Professor Z. Szczurek from the Department of Pathomorphology, Silesian Academy of Medicine, Zabrze for the preparation and histological description of the samples.

\section{References}

Abusafieh A, Siegler S, Kalidindi SR (1997) Development of self-anchoring bone implants I. Processing and material characterization, J Biomed Mater Res 38, 314327.

Alexander H, Weiss AB, Parsons JR (1987) Ligament repair and reconstruction with absorbable polymer coated carbon fibre. Stent J Orthop Surg Techn 3,1-14.

Arru P, Santi M, Vallana F, Majni G, Ottaviani G (1987) A new pyrolytic film for biomedical applications. High Tech Ceramics, Elsevier, Amsterdam. pp. 117-126.

Becker HP, Rosenbaum D, Zeithammel G, Gnann R, Bauer G, Gerngross H, Claes L (1996) Tenodesis versus carbon fiber repair of ankle ligaments: a clinical comparison. Clin Orthop 325, 194-202.

Blazewicz M, Blazewicz S, Chlopek J, Staszkow E (1991) Structure and properties of carbon materials for medical applications. In: Ceramics in Substitutive and Reconstructive Surgery. Vincenzini P (ed.). Elsevier, Amsterdam. pp. 189-195. 
Blazewicz M, Blazewicz S, Wajler C (1994) Mechanical and implant behaviour of chemically modified carbon braids. Ceramics International 20, 99-103.

Blazewicz S, Chlopek J, PowroŸnik A, Blazewicz M (1989) Polish patent Pl/156263/89

Blazewicz S, Wajler C, Chlopek J (1996) Static and dynamic fatigue properties of carbon ligament prosthesis, J Biomed Mater Res 32, 215-219.

Blazewicz S, Chlopek J, Litak A, Wajler C, Staszkow E (1997) Experimental study on mechanical properties of composite carbon screw. Biomaterials 18, 437-439.

Bohem HP (1966) Quantitative analysis of basic and acid groups on the carbon surface. In: Advances in Catalysis. Eley DD, Pines H, Weiss PB (eds.). Academic Press, New York, vol.16, pp. 179-181.

Bohem HP (1994) Some aspects of the surface chemistry of carbon blacks and other carbons. Carbon 32, 759796.

Bokros JC (1977) Carbon biomedical devices. Carbon $\mathbf{1 5}, 355-371$.

Bokros JC, Lagrange LD, Schoen F (1972) Control of structure carbon for use in bioengineering. In: Chemistry and Physics of Carbon, vol. 9. Walker PL (ed.). Marcel Dekker, New York.

Brittberg M, Faxen E, Peterson L (1994) Carbon fiber scaffolds in the treatment of early knee osteoarthritis. A prospective 4-year follow up of 37 patients. Clin Orthop 307,155-164.

Buttazzoni B (1987) Les applications des composite carbones en chirurgie orthopedique (Applications of composite carbons in orthopedic surgery). In: Biomechanique Orthopedique (Orthopedic Biomechanics). Poitout D (ed.). Masson, New York, pp. 106-118.

Carranza-Bencano A, Armas-Padron JR, Gili-Miner M, Lozano MA (2000) Carbon fiber implants in osteochondral defects of the rabbit patella. Biomaterials 21, 2171-2176.

Chlopek J (2000) New materials for orthopedic screws. Acta Montana 117, 14-18.

Christel P, Claes L, Brown SA (1991) Carbon-reinforced composites in orthopedic surgery. In: High Performance Biomaterials. A Comprehensive Guide to Medical and Pharmaceutical Application. Szycher M (ed). Technomic Publishing Company, Lancaster, PA. pp. 499518.

Cieœlik T, Szczurek Z, Chlopejk J, Sabat D, Mêcik T, Stangiewicz A, (1999) Composite carbon elements in treatment of fractures of the mandible, Acta Bioengeneering and Biomechanics. Bêdziñski R (ed.). Technical University, Wroc ${ }^{3}$ aw, Poland. pp. $77-80$.

Czajkowska B, Blazewicz M (1997) Phagocytosis of chemically modified carbon materials. Biomaterials 18, 69-74.

De Santis R, Prisco D, Apicella A, Ambrosio L, Rengo S, Nicolais L (2000) Carbon fiber post adhesion to resin luting cement in the restoration of endodontically treated teeth J Mater Sci; Mater Medicine 11, 201-216.

Donnet JB, Bansal RC (1986) Carbon Fibers. Marcel Dekker, New York, NY.

Feng L, Andrade JD (1994) Protein adsorption on lowtemperature isotropic carbon. J Colloid Interface Sci 166,
419-426.

Forster IW, Ralis ZA, McKibbin B, Jenkins DHR (1978) Biological reaction to carbon fiber implants. Clin Orthop Rel Res 131, 299-307.

Jenkins DHR (1985) Ligament induction by filamentous carbon fibre. Clin Orthop 197, 86-90.

Jockisch KA, Brown SA, Bauer TW, Merrit K (1992) Biological response to chopped-carbon-fiber-reinforced peek. J Biomed Mater Res 26,133-146.

Kain HL (1990) A new concept for keratoprosthesis. Klin. Monatsbl. Augenheilkd 197, 386-392.

Lewandowska M, Komender J, Chlopek J (1999) Interaction between carbon composites and bone after implantation. J Biomed Mater Res (Appl Biomater) 48, 289296.

Louis JP, Dabadie M (1996) Fibrous carbon implants for the maintenance of bone volume after tooth avulsion: first clinical results, Biomaterials 11, 525-528.

Miller JH (1984) Comparison of the structure of neotendons induced by implantation of carbon or polyester fibres. J Bone Joint Surg 66, 131-139.

More N, Baquey C, Barthe X, Rouais F, Rivel J, Trinqueste M, Marchand A (1988) Biocompatibility of carbon-carbon materials: in vivo study using ${ }^{14} \mathrm{C}$ labelled samples. Biomaterials 9, 198-202.

Morris DM, Haskins R, Marino AA, Misra RP, Rogers S, Fronczak S, James AA (1990) Use of carbon fibres for repair of abdominal wall defects in rats. Surgery 107, 627631.

Pampuch R, Blazewicz S, Chlopek J, Gorecki A, Kus W (1988) Nowe Materialy Weglowe w Technice i Medycynie (New Carbon Materials for Technique and Medicine) PWN, Warsaw, Poland.

Robinson ED, Efrat M, Mendes DG, Halperin N, Nevo Z (1993) Implants composed of carbon fiber mesh and bone-marrow-derived, chondrocyte-enriched cultures for joint surface reconstruction. Bull Hosp Jt Dis, Spr, 53, $75-82$,

Strover AE, Firer P (1985) The use of carbon fibre implants in anterior ligament surgery. Clin Orthop 196, 88-98.

Szczurek Z, Pogorzelska B, Sabat D, Cieslik T (1993) Microscopic healing picture of defects in rabbit jaw bones as influenced by carbon cloth. Proc XIV Congress of Pathology, Innsbruck. p. 260,

Vallana F, Pasquino E, Rinaldi S, Galloni M, Gatti AM, Modica F, Benech A (1993) Carbofilm: Present and future applications in biological devices, Ceramics International 19, 169-174.

Zamorska L, Blazewicz M, Papiez M, Zolnierek M, Nowak B (1998) The regeneration and tissue response to carbon implants in rat skeletal muscle. In: Molecular and Physiological Aspects of Regulatory Process of the Organism, Proceedings of $7^{\text {th }}$ International Symposium of the Polish Network of Molecular and Cellular Biology UNESCO/PAS. Lach H (ed.). Pedagogical Univ, Cracow, Poland. p. 134. 


\section{Discussion with Reviewer}

H. Plenk: The significance of the gray level determination and thus the conclusions regarding a degradation process are doubtful.

Author: I did not include the results of the statistical analysis. However, the analysis has been done, and concerned the comparison of the distribution of parameters (skewness, kurtosis, minimum and maximum values, confidence interval, median) at different time-points with the Kruskal- Wallis test, the median test and the MannWhitney test. The results indicate significant (with $p<0.05$ ) correlation of the parameter distribution with the observation time.

H. Plenk: How you can claim that no macrophages containing carbon particles were found between the hightemperature fibers, but then describe transport of particles by macrophages into regional lymph nodes?

Author: Tissue reaction to carbon fibers, in my opinion is not the same as that found for most compatible materials. In general, the thickness of the tissue capsule is supposed to be a measure of the severity of tissue reaction to the implant: the thicker the capsule, the more severe the tissue reaction. The basic assumption is that the more toxic materials will elicit thicker capsules because of the greater amount of adjacent tissue necrosis, and, therefore, the more extensive subsequent replacement with fibrous tissue. Our own studies indicated that carbon fibers (well tolerated, low-carbonized fibers) seemed to produce much less tissue reaction than that seen with many other biomaterials (metals, ceramics). The thin capsule was formed at an early stage and disappeared with time. Transport of carbon particles derived from low-carbonized carbon fibers from the implant site by macrophages was never observed. However, such particles retrieved from the soft tissue were analyzed by Fourier-transform infra-red (FTIR) spectroscopy and showed very significant structural transformation, probably as a result of an oxidation process at the implant site. Such a fiber behaves as an active implant. High-temperature fibers are known to have a wellordered graphite surface (smooth, very low specific surface area below $0.3 \mathrm{~m}^{2} / \mathrm{g}$ ), similar to typical biocompatible carbon materials applied in cardiovascular devices. In the early stage after implantation, the tissue response to such a fiber is even more acceptable, compared to low-temperature prepared fibers. However, with time small particles of carbon are formed because of physical fragmentation. The particles derived from such a fiber are resistant to oxidation and from a chemical viewpoint inert. Transport of small carbon particles to the local lymph nodes was observed only for the longest time of implantation. It is probable that the contradicting findings with the two types of fibers are the result of a difference in susceptibility to oxidation at the implant site.

H. Plenk: In this quality of section it is hard to distinguish any carbon fiber type in direct bone contact.

Author: I agree, but the different carbon fiber types differed in their behavior, and the differences were recognizable. I also agree that the hard tissue reaction to the carbon fibers needs further study. 